\title{
THE WILD AND HOMELY SIBERIA HOW SIBERIAN ESTONIANS PERCEIVE THEIR NATURAL ENVIRONMENT
}

\begin{abstract}
Aivar Jürgenson
Culture is traditionally connected with a specific place. When we speak of Estonian culture, we usually mean the culture that is practised in Estonia. Culture presumes the environment and although in principle such environment could be artificial or virtual, we are not independent enough from real living space to create an absolutely independent culture in this virtual world. This is because in order to create worlds we need archetypes, athough in some cases their influence has diminished after multiple copying.
\end{abstract}

Estonian culture is associated with Estonia. An important source for Estonian culture is the nature of Estonia. Patriotic poems from the time of the national awakening cherished the homeland's nature, filling it with a profound symbolic content. Nature denoted the historical experience of Estonians - natural objects as markers of space, rivers, lakes, hills and landscapes carried deep meaning, evidenced centuries-long existence in the specific area.

Yet it would be wrong to associate Estonian culture with Estonia only, because since the mid-19th century Estonians have, time and again, moved to different corners of the world, where Estonian culture developed further, despite being far from its historical homeland. Leaving their home area did not mean becoming independent from that environment: the alternative to an environment is just another environment. Like Estonia provided material and conditions for the development of the homeland culture, so did the destination country's environment for the culture of the diaspora. The nature of the new homeland had a significant role in adaptation.

In the following we shall observe the relationship of Siberian Estonians with their natural environment. We shall study the relations between the activities in the landscape and the environmental conditions. Not only the living space and what is going on there describes people's relationships with the environment, but also the 
way in which these environments have been described and imagined in different social and intellectual perspectives. One landscape can be described in various ways, depending on the experiential background, needs, interests, giving an aesthetic, economic or, for example, a symbolic character to the description.

The sources I have used are mainly the descriptions of Siberian Estonians themselves, largely letters that the settlers wrote from their new settlements, describing and evaluating the natural conditions of Siberia. Most of these letters were published in the Estonian press (newspapers Olevik, Sakala, Postimees and others). An interesting material on how Siberian Estonians perceive nature can be found in the correspondence of Count Friedrich von Berg, the manor lord of Sangaste, with his former peasants and manor servants who had settled in Siberia and sent him information on the local conditions there. The count, who was famous for his botanical interests (he was called the "Rye Count"), was deeply interested in the nature of the faraway land and asked the emigrant peasants for information, he even asked them to send him seeds of the plants growing there (see Pirsko 1994: 90). The relationship of Siberian Estonians with the natural environment of their home place is also expressed in my interviews with Estonians in Siberia, made in recent years.

\section{STARTING CONDITIONS}

Until the mid-19th century it was not possible for Estonian peasants to become landowners. When it was possible after the agrarian reform, it became a symbol of prestige to hold land. Land acquired several different meanings: 1 ) the ground that is cultivated, 2 ) a source of material existence, 3 ) the homeland that gave identity. When the press, in line with the public opinion of that time, generally criticised emigration and emigrants and gave ironic titles to the destinations of Estonians, ${ }^{1}$ mocked those who thought that in Siberia gold was growing in the trees and people walked on silver (Olevik 1900 No 24), it was not completely untrue: people emigrated, being quite unaware of what was waiting ahead, driven solely by the hope of finding better conditions abroad. Seized with the idea of emigration, people imagined the destination area in intensified col- 


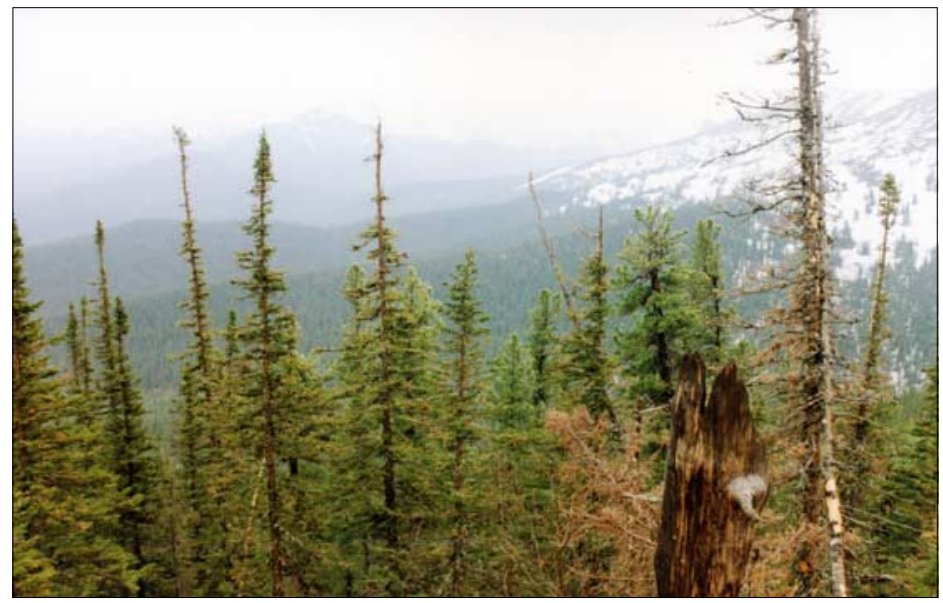

The Sayan mountains. Photo by Aivar Jürgenson, 2000.

ours. Golden land, the land of happiness, etc. were symbols to which the emigrants gave a specific content. Land was the symbol and for agricultural Estonians a golden land or land of happiness primarily meant fertile field land. It was quite normal that there were unreal and reckless fancies about one's own land somewhere far away, which depicted the nature there in vivid colours. The newspapers of the emigration period paint an ironic and hypertrophic picture of the destination countries, as the story went among the people and bore fruit.

An example from the press about Caucasia, which was also a desirable destination country for emigrants:

The land is full of grapes. Last year there had been so many of them that all the ground had been covered with fallen grapes, because there was no one to pick them or eat them and now the land stinks from those fallen and spoilt berries! In the forest there are berries as large as buckets. Some trees that are like appletrees grow apples like thumbs, soft like tinder fungus and sweet like honey. Rice grows there free! Why can't we live there?! It is warm there, no need for overcoats, just eat and sleep without clothes under the grey sky, in the shadow of a thick tree! Go under the vine, a glass in your pocket and just squeeze the grapes, chirr, chirr - and you'll have this dear tipple in your glass. It 
makes one's mouth water to think of that! And if your head becomes dizzy in such hot weather - go climb in the shadow under another tree. (Eesti Postimees 1885, No 10)

The publisher Jannsen in his well-known hostility towards emigration was eager to create such cartoons, but he was definitely right about one matter: the emigrating peasants had a pragmatic economic objective. Among the pluses and minuses of a new settlement, the food opportunities were an important consideration.

While in Caucasia, the Volga area and Siberia it was the fertile land that attracted the emigrants, in the Far East the rich fish waters seemed inviting for coastal people: The Yellow-Sea is yellow with gold, and all the fish are near the coast. Just take a parish certificate that you can hook the bait. There are all kinds of fish in the Yellow-Sea and so many that you could catch the with a bag. At the same time there are ironical descriptions how people who had arrived in the Far East to choose plots had responded and later at home reported:

What a miracle: sprat, smelt, herring, whitefish, vimba, Chum salmon, fat and delicious, sharks, whales and much much more, so what more can your heart desire! And crayfish, a hundred times as big as those in Raudna river, one crayfish, you can say, is just huge like a sieve and has a hundred claws. (Postimees 1904, No 98)

Paradise is the destination of dreams and the place where all desires converge. Virulane writes mockingly that those who have a wicked wife at home, wish to get a new wife in the land of emigration - young, rich, beautiful and strong, who would work for three women (Virulane 1885, No 17).

Such hypertrophic descriptions were not just the creation of journalists. Earlier resettlers, who often showed the situation in their new settlement in a more positive light than it actually was, had their role in shaping such paradise pictures. The first reaction of needy people finding something desirable in their new settlement is humanly understandable. The positive is enhanced, while the negative is treated either neutrally or no notice is taken of it. It was so in Caucasia, where people were enthusiastic about rich veg- 
etation, but did not pay any attention to the unfamiliar humidity; it was so in Western Siberia, where people were happy about the fertile black earth and did not care about windy and muddy autumns and cold snowy winters; it was so in the Far East, where the rich sources of fish were exciting, but the climate unsuitable for grain growing remained unnoticed.

Here a significant factor of emigration becomes evident: it is a process in the course of which one's homeland is changed. The phenomenon of homeland is filled with positive content, homeland is an object in which the paradise motive has an important role. That is why people expect only such qualities from their new homeland that are regarded as valuable, while the valueless or harmful ones are eliminated. The letters the settlers wrote home often carried paradise motives in them and these were accepted in Estonia that was suffering from the "emigration boom".

Insufficient knowledge in the geography of the destination countries indirectly shows how utopian the ideas of the so-called Siberian gold land were. An agrarian home-centred peasant, who maybe never in his life have travelled outside his home parish, had a false idea of distances. Farm people, who were attracted by stories of the fabulous conditions waiting ahead in the foreign land, were ready to leave their home for the unknown. Unknown in the direct sense of the word, because often the awareness of the conditions in the destination country was practically non-existent. Newspapers wrote that all that people knew of Siberia, is that Caucasus stood behind it (Olevik 1897, No 10), Caucasus, on the other hand, was thought to lie just behind Narva (Eesti Postimees 1870, No 21). One group of emigrants heading for East Siberia had seen the towers of Pskov across the Estonian-Russian border and thought that this was their destination, Irkutsk (Postimees 1904, No 98). In the emigration applications often the laconic to the south was noted as the destination (EAA, f. 2054, nim 1, s.-ü 1550, 1). Et cetera, et cetera.

\section{SIBERIA AND THE IMAGE OF SIBERIA}

Siberia was not the first destination of emigration for Estonians, but it surely was the most important one. According to the first census in Russia (1897) the number of Estonians living in Siberia 
was 4000 . However, at that time emigration to Siberia had not yet got full swing. In the years 1906-1914 about 9000 people settled from the Estonian territory to Siberia. This wave of emigration was unrivalled in scope. According to the records of 1924, Estonians had 174 settlements in Siberia.

A few words about the image Estonians had of Siberia at the end of the 19th century and the factors that influenced its development. The image of Siberia, which for many centuries had been predominant in Europe, and to some degree in Russia, also shaped Estonians' vision of it. Although people no longer believed in the cannibalistic successors of Japheth nor the headless people who put food under the hat for eating (Slezkine 1993: 1), the image of Siberia still involved a number of stereotypes. The picture of Siberia included several components, the major ones being: 1 ) the nature (Siberia as a cold, vast and wild country); 2) the past (Siberia as the gloomy place of deportation); 3) the future (Siberia as the land of great opportunities). ${ }^{2}$

While the emigration boom raised the latter much higher than the other components of the image of Siberia leaving those in its shadow, in the course of time the other two also started to become an issue. From these components stem the symbolic constructions that reflect the canonical aspects of the image of Siberia in the letters that the settlers wrote home later. Leaving the second and the third component aside in this article, we shall concentrate on the first: Siberia's impenetrable forests, freezing cold and wildness are metaphors, which are frequently read in the letters, emphasising the extraordinary conditions in the settlement. The harsh nature became more and more important in the vision of the settlers who had overcome their first excitement.

\section{THE NEW HOME THROUGH THE EYES OF SETTLERS}

The impact of the natural environment on people is mostly dual: material and emotional. The connection between these aspects is clear: the economic perspective as an important framework provides its viewpoint to the aesthetic perception of nature. Landscape, the visible quality of the new place of settlement, was often the principal consideration when selecting the destination for emigra- 


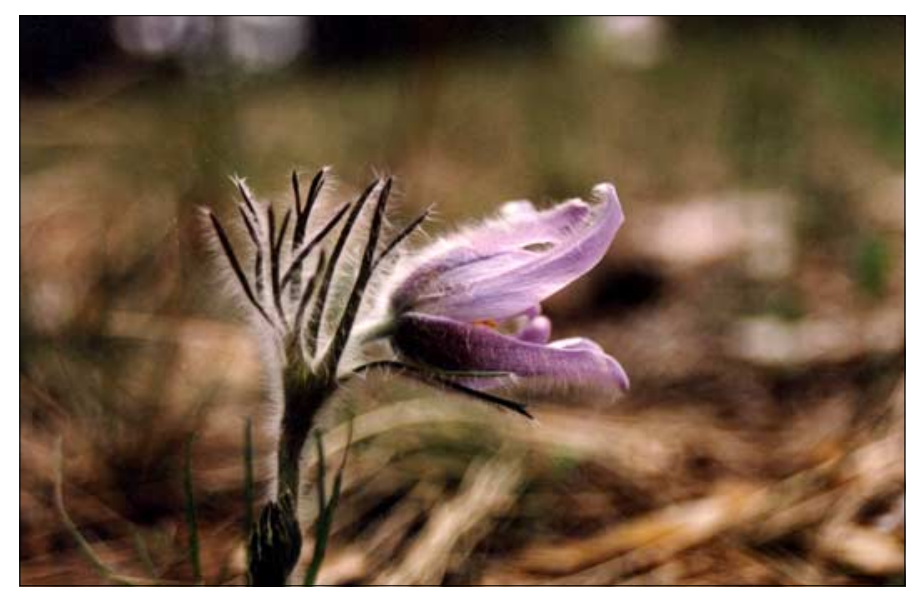

The flower fields in the Sayans are comparable to those in the Swiss Alps. Photo by Aivar Jürgenson, 2000.

tion. Homeland is created according to learned patterns: the new homeland should be the idealised and selected reflection of the former one. The customary natural objects, landscapes, climate - these factors often became decisive in choosing the new place of living. In a foreign country the eye was looking for something familiar in the open landscape, yet what it often found was strange.

The surprises that the emigrants were faced with in Siberia were maybe not as great as those in Caucasia:

The first travellers were looking for a more even land and found it in the deep valley of the river Kodor, where the soil is poor, where the soil consists of big and small river-bottom stones with black sandlike rubble on top of it, because all of the finer earth has flown with the waters into the sea [---]. In the older settlement, where the settlers did not know any diseases as late as in June 1884 , everyone dreamed to have a lower place. When he could move, he gave a few extra roubles on the deal. His place, which was about 5-600 feet up in the mountains, was first rejected because of being high and mountainous. In the Estonian village in Kodor Gorge now nearly everyone was sick [moist and unhealthy air A. J.], the mountain village, Linda, is now much more promising. [---] If only the sons of Estonian plain land would dare to start living in the mountains. (Valgus 1885, No 12) 
While in Caucasia the settlers looked for customary plain landscapes, in Siberia they were afraid of settling down in plain steppes and preferred forest areas.

As seen from above, the nature component of the Estonians' vision of Siberia included different symbols, which the emigrants started to test out in their daily life in their new settlement. First, the extreme climate in Siberia, which the settlers had to experience. The word cold as an epithet of Siberia (the cold land (Postimees 1897, No 222), the land of harsh climate (Postimees 1897, No 223), the harsh cold land (Olevik 1897, No 40) was emphasised in the settlers' letters to Estonia. Cold snowy winters is a subject that added weight to the settlers' letters, confirming the customary image of Siberia. The snowiness of Siberian winter is described by Meinhard Mühlenberg, schoolteacher in the settlement at Om: Instead of buildings you can see huge snowdrifts with smoky-black openings, which show that in those snowdrifts people are living (Kündja 1884, No 15).

They write about severe winter storms, the burans, as well as the ground that was frozen to the depth of up to ten feet and the crevices in it: Some crevices were 4-5 inches wide and similar to ice crevices on lakes and seas (Tallinna Teataja 1915, No 172). They write that in Siberia winters are colder than in Estonia without being damp (Elu 1908, No 129) - a comparison that can be heard in Estonian settlements even today.

Siberia is cold, but it is also wild. The clichés about Siberia used in the written word reflect this canonical aspect of the image of Siberia to the extent that Siberia and the forest are inseparable. Siberian forests (Postimees 1900, No 123) is a metaphor and a concept of definite meaning, just like a bottomless hole swallowing Estonia's sons and daughters for ever. During the coursed time, quite a lot of Estonians have left their homeland due to different reasons, alone and by families, and settled in Siberian forests and steppes (Eesti Päevaleht 1918, No 8).

The Siberian forest is described as follows:

Trees are there so close to each other and their branches so intertwined that the sun cannot get through to dry the land, which is 
covered with a thick layer of fallen twigs. That is why there are no horse tracks or paths in the taiga. You can go in that thicket only in winter, when the debris is covered with snow. (Sakala 1894, No 26)

Siberian forests really seemed like another world to the settlers, like something inhuman and strange: Here in a parish you can find such a primeval forest - the taiga - which no one has ever entered (Postimees 1899, No 144). Siberia is a place where even the crow has not carried its bones (Sakala 1897, No 9).

The impenetrable forests on the one hand and the vastness of the territory on the other hand are images that often stand side by side, providing a double description to the novel conditions in Siberia. Siberia is covered with endlessly large forests and filled with numerous wild animals [---], the northern part is covered by endless moss bogs, called the tundra (Sakala 1894, No 13). Other symbioses of Siberia also help to underline the vastness, for example the wide Siberian steppes (Peterburi Teataja 1911, No 62). The boundlessness of Siberia gives it a tinge of gloom: Thus our brothers and sisters are lost just like behind the clouds and under the ground (Sakala 1894, No 13). The unfamiliar dimensions obscured the landmarks, created a chaos - it was uncontrollable like a cosmic flow. With its vastness, Siberia seemed so unmanageable and terrifying.

While the vastness of Siberia could make the first emigrants feel uneasy, today the boundlessness of Siberia, symbolised by the largest river basins in the world and the deepest lake in the world, is rather an attribute suggesting pride and immortalising life as a Siberian. The vastness of the nature is part of the Siberian identity. This will soon also lead to the vastness of the artificial environment (see e.g. Smith 1977). It took me some time to understand why my Estonian host in Krasnoyarsk called together all the relatives and took a distant visitor $40 \mathrm{kms}$ from the city to see the dam of the Divnogorsk power station. Later I found out that it was a dam that had been the largest in the world after it was completed. Now larger ones have been built, but the aura is still there. Not exactly beautiful, but the largest.

An essential part of the image of Siberia is also the image of a Siberian. Just like wildness and enormous size are important com- 
ponents of the Siberian image, an inhabitant of Siberia is also wild and big. Records say that ruthless mind and cruelty rule among the emigrants (Sakala 1892, No 4). The inhabitants of the Siberian taiga [have] run together from all the four winds and each is fighting against others to survive (Postimees 1900, No 93). The new settlers often write about the outrageous drinking of the earlier ones (the so-called old Siberians) and the lewdness of women - i.e. in a wild land wild people live.

The Estonians who were deported to Siberia in the 1940s and came into contact with the local people also described Siberians according to the earlier stereotypes. The descriptions include elements that show the Siberians as powerful and robust: The hosts are a family of big, strong people with wide Siberian jaws. Although as a rule a Siberian is not greater in size than an average European, the associations and stereotypes are what make Siberians look like giants.

Siberian Estonians themselves have expressed their belief in that they are physically more powerful than others - as if contact with severe natural conditions had shaped a tougher and stronger human type. There are also other popular reflections of the climate theory found with Siberian Estonians. In Vana-Viru village in Omsk oblast they said that when a Siberian Estonian had visited Estonia, the landlady had been surprised when the visitor was going to bed that the latter was not covered with hairs. An Estonian from the Tsvetnopolje village in Omsk oblast M. (born 1951) was convinced that the severe climate had made the Siberian Estonians' hair darker.

Climate has had a psychological, if no other, effect on Siberian Estonians: the Siberians who are used to the continental climate often give reasons why they do not want to live in Estonia - in Estonia the climate is damp and unhealthy. To support this conviction, they give numerous examples of people who had moved from Siberia to Estonia and died after some time. There are also many of those who had moved to Estonia but soon returned to their home place, supposedly because of unsuitable weather.

So the circle has closed: while the first Estonian emigrants to Siberia were scared by the continental climate conditions, their descend- 


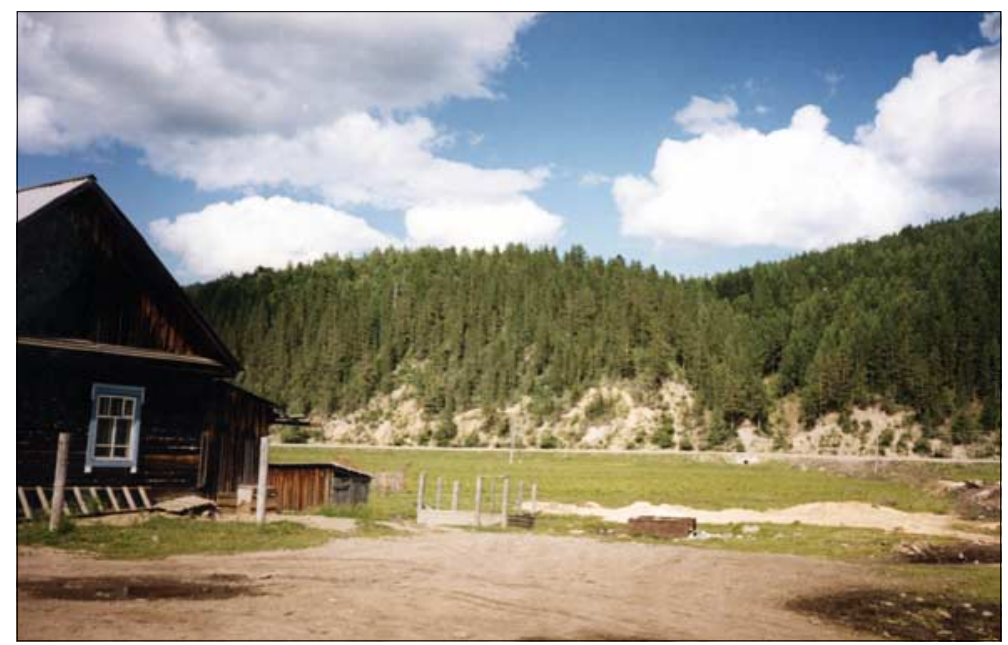

Narva village in the Krasnoyarsk region. Photo by Aivar Jürgenson, 2000.

ants fear the maritime climate of Estonia. The familiar environment of home place has a significant impact on an individual. The depth of such impact often becomes evident only when one moves to another environment. Although psychological factors play a decisive role in adaptation, changes caused by the changed environment often also exert physical influence.

\section{NATURE DESCRIPTIONS OF THE NEW HOME PLACE}

What was important for an Estonian emigrant with agrarian background was the agricultural land and so at first in their letters to homeland, the settlers did not pay any special attention to experiences of nature. It was the same everywhere, where Estonians migrated. Everywhere they experienced the unusual and the strange, unseen landscapes, but without the aesthetic appreciation of nature, like for example an urban person would see it. For instance, Caucasia, where Estonians travelled already before emigration to Siberia, amazed people with its singular landscape, but most reactions and estimates were accompanied by the peasant's pragmatic attitude. For example, between the mountains sometimes very strong winds blow, but first and foremost, the wind blows 
through the peasant's reference framework; i.e. it blows so strong that it damages all the fruit trees in gardens, if you have planted those (Valgus 1885, No 12).

The economic undertone of nature descriptions is also noticeable in the letters of Siberian settlers. One of the first nature descriptions from Estonian settlers in Siberia (Upper-Suetuk village in the foothills of the Sayan Mountains) reads as follows:

This place is very beautiful and the land is very mighty there. People get 12 or 15 bushels of grain from one bushel without using manure (shit). There are many forests, so that people get enough wood. In the south the Altai Mountains are seen, like a good old man, whose hair is white, but legs still strong. Perpetual snow covers the tops of the Altai Mountains, but on its slopes and valleys is quite a temperate and very good weather. Melons and water-melons, which are grown in balls under glass in Livonia, grow like potatoes in the field in Upper-Suetuk. (Tallorahva Postimees 1857, No 4)

This description by Kossmann, the pastor of Irkutsk, provides an example for the later nature descriptions in emigrants' letters.

The agrarian undertone of a nature description can also be seen in the following letter written by a person who went to examine the lands and the conditions in Siberia. The selected extract begins with describing the journey to Siberia:

As we travel further and reach the Ural Mountains, the landscape becomes more and more beautiful. In the middle of the mountains, near Yekaterinburg, there were a number of very beautiful lands and fields. Further to Chelyabinsk, the landscape remained more monotonous, but the field land looked excellent. Meadows were as if scattered with heaps of grain. [---]. After three days' journey we came to the Kolonia station, Tykalinsk county, Tobolsk region. On this road nothing else was seen than boundless steppe, scattered with small birch stands. No other trees than the birch and the sparse aspens can be seen. When we got out at Kolonia station, we went to the nearest Estonian village that was about $1^{1} /{ }_{2}$ versts away from there. There we wandered quite widely around. Now, what was there! The earth is black as soot. 
The layer of black earth is $1^{1 /}$ archins thick. In every respect, wonderful grassland, from which you get the best field with the minimum effort. No stones to find, even for the sauna stove. If necessary, instead of stones bricks must be used, which are always available here. (Meie Kodumaa 1908, No 1)

The letter is economically oriented because of the man's task to present primarily information about the agricultural conditions in the foreign country.

The pictures of landscapes published in the press were usually dispassionate and had an (agrarian-) economic undertone:

Where there are rivers and lakes, the ground is more mountainous and better for grain growing where there is sufficient forest, there it is easy to build, more frequent showers are there and the black topsoil is not too fatty nor afterwards light like coffee powder. Where there are sealike open plains, there are not so many midges [moshka] attacking you, but in a dry summer you cannot expect bread and hay, and you have to bring building and heating material from twenty or more versts. However, where the forests are too large, there is hard work, too many midges, and the frozen ground, which spoils the crop for many years in a row. (Sakala 1901, nr 13)

In the last decade of the 19th century and at the beginning of the 20 th century the Estonian press published numerous letters by Siberian settlers, reflecting their everyday life thousands of kilometres away from homeland. Briefly they also dealt with the local nature. The following extract is from the letter of a settler living in Southern Siberia:

In the places near mountains you can find stones and pure gravel surface. In the mountain crevices in some places pines grow, but it is very complicated to get them because of the rocky and steep slopes and in some places, because of the distance. (Sakala 1910, No 26)

The natural conditions are also characterised merely from the aspect of agricultural interest in a letter sent from the Estonian settlement in Upper-Bulanka: In the location of the Estonian settle- 
ment here [---] the landscape is very beautiful the land is fertile there are many grasslands, and that is why cattle-growing is a success here (Olevik 1893, No 1). The same is true for a letter from the Far East: The terrain here is mountainous, mostly high, with steep slopes, so that in many places it is even impossible to cultivate it with plough animals (Postimees 1904, No 38).

A letter sent from Mariinski region, Tomsk province, reads: A river rich in fish flows through our settlement. In this place the land is covered with black topsoil (chernozem) and it is fertile, if cultivated (Olevik 1903, No 12).

While elsewhere in Siberia the main activity of the settlers was field cultivation and partly cattle-breeding, in the Far East it was fishing. So the settlers' descriptions of the nature conditions there are tinted by fishing interests.

The sea below the Estonian villages is quite calm [and good for] weir fishing in summer; but in winter it is very rough below the ice and not suitable for using bag nets. (Postimees 1904, No 39)

So, the nature descriptions of the settlers flow smoothly into reflecting economic interests, whichever the place in Siberia and whatever the conditions. There are virtually no nature-aesthetic vignettes in the letters of the settlers of the earlier period. For a peasant, landscape is the working field, like the workshop for a craftsman. And nobody expects a workshop to be primarily beautiful, but functional.

Speaking of the landscape, the aesthetic experience remains in the background and attention is paid above all to the economic use, and the same is true for natural objects. These are mentioned mainly in connection with the opportunities of economic use. The natural objects are regarded in the letters like crops and products, which can be consumed and which have their price.

In August people go hunting in the mountains and gathering hazelnuts, the price for a pood of nuts is 90 kopecks now. There are enough animals to hunt. In larger forests are elks, deer, bears, wolfs, black and red foxes, sables, wild oxen, hare and different types of birds (Sakala 1910, No 11). 


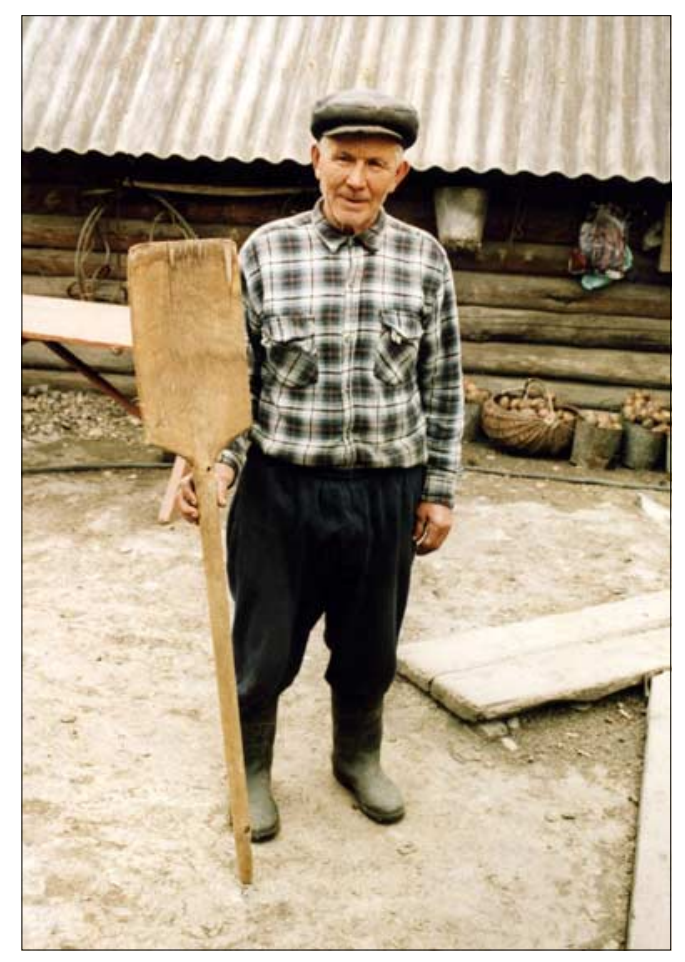

The Esotnian that has killed a wolf with a spade. Krasnoyarsk region, Motorski village. Photo by Aivar Jürgenson, 2000.

Beside the huge dimensions, cold and snowiness, the inherent aspects of the typical vision of Siberia in the 19th century and beginning of the 20th century were also the wild animals and insects there, regarded as particularly dangerous. Yet, even their hostility to humans is expressed in relation to people's agrarian activities: In forests and steppes bears and wolves were their [Siberians'] deadly enemies, which is affirmed by the fact that in a village bears had killed 40 horses during one summer. Records talk about the forests that are packed with wolves and bears, and how wolves and bears prowl around in villages (Rahva Päevaleht 1909, nr 27). The number of wild animals and their impact on their daily life was disturbing for the settlers and so it is understandable why this topic was so frequent in letters sent home. It is a fact that in Siberia the Pritajozhnyi village was renamed Linda, in hope that the name of Estonian folk hero's mother would scare away wolves and bears (Maamägi 1980: 13). 
The fact that the large Siberian predators are mentioned in the letters of the settlers is an evidence of their symbolic meaning. Just like the cold, the forests and the vast expanses were symbols of Siberia, so were the predators. Bears and wolves have largely remained the symbol of Siberia even today. All kinds of stories about meeting them are among the favourite topics of Siberian Estonians. Particularly it is the bear, whose visits to the villages or bringing bear cubs home are often recalled. A hunter's capability is expressed in the number of bears he has shot. The symbolic meaning of the bear is also expressed in the fact that the Siberian willingly calls himself the Siberian Bear.

An inevitable phenomenon in Siberia is also the abundance of insects there, which is a curse for both people and animals.

The animals also have to suffer much pain because of horseflies, drone flies, mosquitoes and different midges. There are crowds and crowds of them so that you often need to make smoke all night on the pasture to protect the animals and people have to cover their faces with a net or veil. (Sakala 1897, No 9)

For the settlers the abundance of mosquitoes (mosks, moskitos) served as a reason for the low milk yield of Siberian cows (Postimees 1910, No 293). To scare away the insects, manure heaps were lighted near houses, and the heaps smoked for months. As protection from mosquitoes, face nets were worn and the more sensitive body parts were covered with tar (Kündja 1891, No 3; Postimees 1899, No 145; Olevik 1900, No 24; Vabadus 1907, No 28; Rahva Päevaleht 1909, No 147; Sakala 1911, No 152). While the emigration also included remigration, i.e. all the settlers did not adapt to the new situation and returned home after some time, according to the returned migrants one of the reasons for returning was just mosquitoes.

Just like bears and wolves, the inconvenient mosquitoes belong to the conversation topics of Siberian Estonians today. Now, too, manure heaps smoke on the outskirts of villages, and you cannot do without face nets either. In Viruküla people talked of a six-year-old girl, who got lost while picking berries in the forest. When she was found, mosquito bites had caused her such a blood loss that the girl died. Cattle are sometimes said to suffer similar death. 
The first settlers were disturbed by the widespread field pests who were unknown in their former homeland, so that they did not even know how to name them in Estonian:

In some years the so-called "kobõlkas" cause much trouble. These are pests, similar to large grasshoppers - sarantsa - which live for several years. For example, in 1901 and 1902 they stripped the whole southern part of Siberia. All the grain in the fields, the hay on the meadows, even the tree-leaves in forests fell into the pests' share. (Eestlane 1906, No 21)

Mart Uhke from Baltiskaia village in Russia writes to his former landlord, the count of Sangaste, Friedrich von Berg:

And I inform you that in our country this year in summer was again a specific crop failure as it often happens here on the plain land, last summer 1887 here were such animals that live in the ground, big as rats, and they call them susliks here, and there were infinitely many of them so that they ate our grain at the time of growing, so that we have had very little bread. (cit Pirsko 1994: 88)

In the letters of the settlers from the late first decade of the 20th century one can already find nature experiences; i.e. paying attention to such phenomena, which are not exactly connected with the daily work of a peasant. Mostly they speak of the colourfulness and floweriness of the Siberian nature. The nature-aesthetic pictures of the Estonian settlements in Siberia often had a cheerful undertone and underlined the beauty of this place. In the months of May and June everything here is like a sea of flowers (Sakala 1910, No 27). From Jenisseisk province, Kanski region:

The countryside here is really very beautiful, especially in May and June the landscape is so wonderful that in Estonia you cannot find such even in flower gardens or manor greenhouses. Several hundreds sorts of roses, peonies and flowers are blooming everywhere, which rock and wave like a sea of flowers in the wind. The mountains are especially nice with their cedar forests, but also the woodless, bare, white rock mountains, which look like mountains of snow from a distance, (Sakala 1910, No 11) 
But there are also nature descriptions with a different undertone, like for instance the following extract from a letter from the Om settlement:

The nature in Om settlement is poor and monotonous. There are no such forests here, no flowers, no wild animals or birds that are so usual for us in Estonia. All the beauty of the woods here is the small birch stands, with an occasional aspen. In lower places, where rainwater does not drain into the ground, you can find some willow thickets in some places. Attempts have been made to plant decorative and fruit trees in gardens, but with no resultall of them dry. The same is with flowers. Globeflowers, dandelions, vetches and sppedwells are here the same as in Estonia. Apart from these there are two or three more flowers with thick and rough leaves - and that is all of the flower selection in the Siberian Barabinski steppe. (Tallinna Teataja 1915, No 172)

In this letter two aspects should be pointed out. The negative evaluation of the landscape on the one hand and comparison with Estonia on the other give evidence of the non-adaptation with new natural conditions. Estonia's cultural impact was so great on the first generation of settlers, the evaluation criterion for the new settlement was the former homeland. People were ready to acknowledge new environmental conditions, but internally they still felt alien. It took a long time before the nature in the new settlement became familiar. Most probably, for the first generation of emigrants it never became familiar. Only those who were already born and spent their childhood there, could accept it as familiar.

Childhood often provides the framework in which an individual acquires preferences about objects and places. The subject receives signals from the surrounding environment, and responds according to what he/she has acquired in the culture. Different signals come through the framework that has been shaped by previous immediate and indirect experiences.

A Siberian Estonian from Upper-Bulanka village, now living in the city of Minussinsk, meaningfully opened the time measure of the home place environment:

There is nothing for me to do in Pulan. What shall I do there? But those mountains, waters where I went swimming, those will 


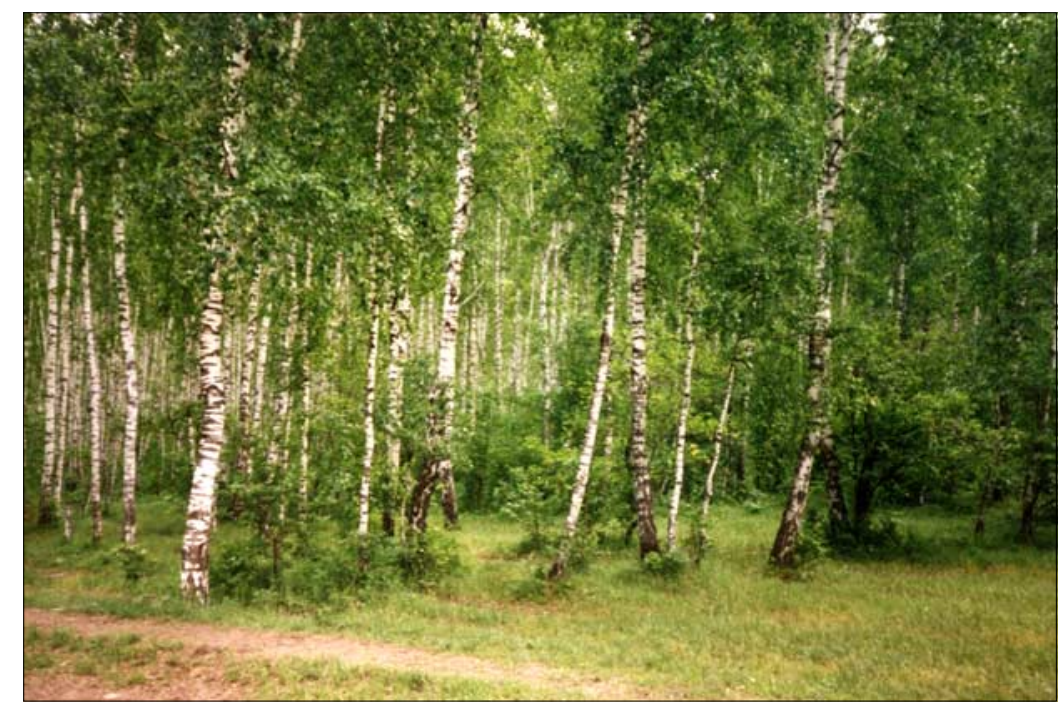

Birch forests are typical of South Siberia. Karatuz, Krasnoyarsk region. Photo by Aivar Jürgenson, 2000.

remain. Those twenty or so kilometres [i.e. the radius of the home place]. Rodina [in Russian: homeland] - is the home village where I grew up, where I was born. The river in my home place is rodnaia [homely], there I went swimming as a child. Rodina ne natsionalnaia, rodina vrazhdionnaia [Homeland is not about nation, it is inborn].

Natural objects help to render meaning to home place. Local entities, both natural and cultured landscapes (fields, pastures, etc.) have a background: the lake is primarily a lake for swimming and fishing, the forest is berry and mushroom forest, the meadows are connected with tending cattle in the childhood. The natural objects as the retainers of memories and more broadly, retainers of the whole history of the settlement acquire the measure of a symbol and together they make up one's homely territory.

Although the senses provide the same opportunities for people to sense the surroundings, what is actually experienced is still different. This difference is due to different cultural background, in which the impact of customary, one's own environment undoubtedly plays its role. In time the entities of the new environment become more and more acceptable and while in an extract above presented, an 
inhabitant of the Om settlement complained about the monotony of the Siberian environment, only the small birch stands giving some colour to it, in the eyes of the next generations, the local nature aesthetics gains the value of a symbol of the home place. The generation of Estonians born in Siberia sees the nature in their home place as familiar. Most often the birch is named as the favourite tree. This is not a random choice: numerous birch stands round the settlements, especially on the West-Siberian plain, account for the majority of stands there and are best associated with the home place.

In Orlovka village in Omsk oblast, a woman who was born there in 1938 spoke about living for years with her military husband in Buryatia. Unfamiliar environment, unfamiliar people, but in the woman's story what acquired symbolic significance was the trees. Years later she vividly described how, wandering in the unfamiliar Buryatian coniferous woods, she noticed a common birch. The emotion that had overwhelmed her then was genuine even at the time of narrating: Beriozka moija milaja! 'Birch, my love'. Clapping hands, she recalled the thrill that overcame her when she saw a familiar tree thousands of kilometres away from home.

\section{ECONOMIC USE OF THE FOREST}

Adaptation to novel nature conditions was vital for the first settlers and it took place, while getting used to environment associations. At the same time, human activities substantially changed the environment. Many letters of the settlers (e.g. Olevik 1897, No 33) and later Siberian Estonian narratives reveal that when the first settlers came, the territory of the future settlement was covered with forest. Forests belonged to the settlements, but were not divided by the settlers, being in the possession of the community. People started to redesign the environment according to their desires.

Restructuring is a human, cultural activity and it gives an identity to the person. Landscape is an important source for determining where the person belongs. Creating a human environment out of wild surroundings is nearly the same as shaping order out of chaos in this way the surroundings acquire a meaning and become a living space. Over the years, the natural landscape became a cultured 
landscape in the Siberian Estonian villages, too. Where once forests rustled, now green grain fields flow - such cliches are often met in the letters of Siberian settlers and travellers in the last quarter of the 19th and the first decades of the 20th century.

Transformation of nature often also has its shady sides. Limitless logging caused receding forests. Burning dead grass in spring, a general and deep-rooted custom, according to some informants even an order from the parish administration (Sakala 1894, No 27), destroyed much forest, especially the young trees, but the peasant pragmatism even found a justification for that: the flames scare away wild animals and snakes and the burned land is easier to cultivate (Sakala 1894, No 27; Pealinna Teataja 1915, No 203).

The promotion of ecological thinking has undoubtedly had its impact on modern people, so that the following "aesthetics" might seem strange to them. Yet it is quite typical for a nature-conquering agrarian colonist: It is quite nice to see in the evening how the forests on the mountains burn in thousands places, when the fire goes out in one place, it lights up in another (Sakala 1894). So that if we have previously stated the scantiness of nature aesthetics in the letters of Siberian Estonians, it could not be due to the lack of the sense of beauty: the aesthetic experience gained from the forest fire is a telling evidence of it. It is true, there are also disapproving letters, complaining about the receding forests because of unsustainable nature management. According to the letters, young forests survived only in places inaccessible for the flames. Forest fires lasted for days, until the first rain put them out (Sakala 1894, No 29).

Different reasons are given for burning dead grass, which has been practised during all the time Estonians have lived in Siberia. While in early settlers' letters it was justified as facilitating fieldwork, scaring away wild animals and snakes or even slash-and-burn agriculture (Sakala 1894, No 29), today extensive grass burning is defended in a different way. Some years ago, collecting ferns started on the initiative of Japanese purchasers (the Japanese use ferns for food and following their example, fern salads, etc. are prepared in Russia, too) and this has become a new source of income for Siberians. In spring people gather in crowds to go and pick young fern shoots. Another justification for burning the grass is that it is easier to pick fern shoots from the burnt land. 
Although grass burning has occurred spring after spring during many generations, an informant's opinion of it was the following:

Interviewer: But why do they burn [the grass]?

Informant: You see! Interesting for them to look at! Some go burns it, [to] burn the edge of grassland, to clean it, where it has overgrown. But now the whole forest... They let it burn, then... Young forest and everything burns. Nobody cares any more. The young, young, young. It is not the old who do it, but those young people they burn it. Interesting for them to look at.

Forests were managed uneconomically when the birch tar was made. Birch tar was among the most profitable sources of income for Siberians. Countless numbers of birches were barked and the tree trunks were left to dry in the forest. Oh those birches that were murderously destroyed then, an inhabitant of Om recalls the early times of the settlement (Olevik 1897, No 33).

The settlers' letters also speak about the unsustainable storing of firewood. Only tree trunks are taken out of the forest, cut high from the ground, the rest is left to decay (Olevik 1894, No 23). Nobody thinks it is necessary to keep it [the forest], everybody tries to cut as much as he can (Postimees 1899, No 159).

Especially extensive was the logging in places where it was possible to transport and sell the forest, for example near large rivers. In 1899 all the forest was declared state property and laws were adopted to protect the woods, forest managers were hired and afterwards everyone had to apply for a logging permit (Sakala 1899, No 4; Postimees 1899, No 159; Uus Aeg 1901, No 9). A message from Om settlement describes the reaction of the settlers to the notice of forest nationalisation as follows: if the forest becomes state property anyway, it makes no sense to keep it any longer - during three weeks logs were taken out of the forest, days and nights. Not the whole trees were taken home, only the thick trunks, two fathoms long, and the rest was left to decay in the forest (Postimees 1899, No 159).

Burning dead grass, logging for sale and for firewood near the villages, but also making birch tar caused the forest edge to recede further and further away from the villages, so that later even con- 
struction timber often had to be brought from tens of kilometres away. The settlers' unauthorised use of forest was a serious problem, which had to be restricted by the authorities. At the end of the 19th century foresters were hired.

In the opinion of the Siberian Estonians today, one of the most important qualities of Siberian nature is its purity. The Siberian taiga, with its waters, fish, etc. is regarded pure due to the low density of settlement. According to the estimate of an informant, local vodka tastes better thanks to the cleanness of the local water.

The second value of the local nature in the eyes of Siberian Estonians is the natural resources.

Neft [oil] is all here in sever [in the north], gases and everything is here and. Gold and coal and - everything is in Siberia, everything. Iron ores and. Everything is here.

To a certain degree they are proud of the local natural riches, which is something to be proud of, in comparison with other, poorer areas of Russia:

But those... coloured metals are nowhere else to be found but here in Krasnoyarsk region. In Russia, there in Rossiya, it is nowhere else to be found any more.

At the same time a painful attitude to the local environment-polluting aluminium plant can be detected. Excavation of natural resources is seen as hazardous to the environment:

Here they damage these mountains, take there every damned stuff: ores and the coloured... tin, and... everything there is. Tin and those coppers and aluminiums and iron ores and.

The nature aesthetics for a modern Siberian Estonian is the aesthetics of the home place. They speak of the beauty of the nature as the beauty of one's home place. Quite often it happens by means of the mirror mechanism: descriptions express how strangers have praised the beauty of the local nature. Underlining the values through others seems more persuasive than sharing one's own evaluations. 
The emphasis on the aesthetic value of Siberian nature is particularly evident in the narratives of those who live further away from the home place, for example in Estonia. Specific places - also the manmade objects (villages, etc.) are associated with the environment, the seasons, the sensual experiences of nature. A nostalgic tone, which accompanies the Siberian Estonians living away from their home place, first and foremost covers natural entities and landscapes.

A former inhabitant of Upper-Bulanka village, living in Estonia since 1984:

It took quite a long time before I got used to this [Estonian] nature and roads and asphalt and... This was utopian that... It is not so easy! But I was young [---]. If I had found nature... here like, let us say... which would be a bit similar to that Siberian nature, I think I would have adjusted better. But there wasn't! So it was very difficult for me to get adapted to it.

In the story of the same informant Siberian nature is opposed not only to Estonian nature, but also to the nature environment of another Estonian village which is twenty kilometres away:

Maybe I feel I was born in Pulan - the nature in Pulan is much more beautiful than there in Suetuk. [---] Even that fog, when it starts coming from the mountains... Oh I like it very much. As if you step in milk - or I even cannot say, it is so fantastically nice and beautiful and... And those flowers, how they grow there and in my opinion even the dogs bark differently. Dogs bark differently. And the mountains! But the strawberries that are there!

Even after a dozen of years in Estonia, the former Siberian has not got used to Estonian nature:

I told you right away that I don't like the nature here [in Estonia]. It is not to my taste. It is for me like nature... like nature. But it does not offer anything to my soul.

The same informant also said that what is attractive about Siberia is primarily the nature there.

The nature of the home place acquires a higher value especially for Siberians who live abroad. Nature symbolises intimate social-cul- 
tural bonds and provides an unworldly colouring to the home place in the memories. It is not just a geographical place, but a subjective space that holds past experiences: a landscape with mountains and valleys, forests, weather conditions and water-bodies. Although marked with objective phenomena, the nature environment is really a subjective field, charged by a framework of senses, which has been created during one's lifetime. If the nature descriptions in the settlers' letters a hundred years ago were descriptions of an unfamiliar place, the economic aspect of which is mainly of interest - in the course of time aesthetic and familiar colouring has been added to the nature descriptions. The nature descriptions of Siberian Estonians today are descriptions of a home place and they give evidence of local Siberian identity.

\section{Comments}

${ }^{1}$ The emigration destinations were ironically called the land of happiness (Olevik 1885, No 18; Olevik 1885, No 28; Meelejahutaja 1885, No 17; Virulane 1885, No 14; the land of milk and honey, the land of grapes and figs (Tallinna Sõber 1885, No 8); the golden land (Perno Postimees 1884, No 39; Eesti Postimees 1869, No 9); the famous land (Tallinna Sõber 1885, No 11); the land where milk and honey flow (Tallinna Sõber 1885, No 25; Kündja 1885, No 27/28); the blessed land (Perno Postimees 1884, No 37; Perno Postimees 1884, No 39).

${ }^{2}$ Also the Old World's American dream depicted the opportunities waiting ahead there, opening to those who are not afraid of hard work.

\section{References}

Maamägi, Viktor 1980. Uut elu ehitamas. Eesti vähemusrahvus NSV Liidus (1918-1940) [Building a New Life. The Estonian Minority in the USSR (1918-1940)]. Tallinn: Eesti Raamat.

Pirsko, Priit 1994. Sangastest Samaarasse ja Siberisse [From Sangaste to Samara and Siberia]. Harri Kübar et al. (ed.). Bergid ja Sangaste. Lehekülgi Sangaste kihelkonna ajaloost. Tartu: Tartu Ülikooli Kirjastus.

Slezkine, Yuri 1993. Siberia as History. Galya Diment \& Yuri Slezkine (eds.). Between Heaven and Hell. The Myth of Siberia in Russian Culture. New York: St. Martin`s Press, pp. 1-6.

Smith, Hedrick 1977. The Russians. London: Sphere Books Limited. 